\title{
OPEN
}

Published online: 11 February 2020

\section{Author Correction: Altered humoral immunity to mycobacterial antigens in Japanese patients affected by inflammatory demyelinating diseases of the central nervous system}

\section{Davide Cossu, Kazumasa Yokoyama, Yuji Tomizawa, Eiichi Momotani \& Nobutaka Hattori}

Correction to: Scientific Reports https://doi.org/10.1038/s41598-017-03370-Z, published online 09 June 2017

The Acknowledgements section in this Article is incomplete.

"Davide Cossu is an "overseas researcher under Postdoctoral Fellowship of Japan Society for the Promotion of Sciences"'”

should read:

"Davide Cossu is an "overseas researcher under Postdoctoral Fellowship of Japan Society for the Promotion of Sciences". Yokoyama Kazumasa and Hattori Nobutaka research studies are financially supported by Ono Pharmaceutical, Mitsubishi Tanabe Pharma, Hydrogen Hearlth Medical Labo, ABIST, Melodian, Daiwa, Biogen Idec Japan, Bayer Yakuhin, Nihon Pharmaceutical, Asahi Kasei Medical, MiZ and Kenkokazoku. All Authors report no competing interest."

(i) Open Access This article is licensed under a Creative Commons Attribution 4.0 International c. License, which permits use, sharing, adaptation, distribution and reproduction in any medium or format, as long as you give appropriate credit to the original author(s) and the source, provide a link to the Creative Commons license, and indicate if changes were made. The images or other third party material in this article are included in the article's Creative Commons license, unless indicated otherwise in a credit line to the material. If material is not included in the article's Creative Commons license and your intended use is not permitted by statutory regulation or exceeds the permitted use, you will need to obtain permission directly from the copyright holder. To view a copy of this license, visit http://creativecommons.org/licenses/by/4.0/.

(C) The Author(s) 2020 